\title{
ANTROPOLOGIE SOCIÁLNÍCH VZTAHŮ V SOUDOBÉM VIETNAMU
}

\author{
Michal Schwarz \\ Masarykova univerzita, Filozofická fakulta, Seminář vietnamských studií, \\ Arne Nováka 1, 60200 Brno, Česká republika \\ e-mail: schwarz@phil.muni.cz
}

\begin{abstract}
Abstrakt
Recenzní článek přibližuje publikaci o etnografických, lingvistických a sociálních vztazích v rodinách, které zůstaly po válkách ve Vietnamu. Někteří členové rodin stále čelí poválečným tlakům a postižením válečnými traumaty. Jiní čelí sociálním imperativům péče o staré nebo nemocné př́buzné. Omezení v osobním životě jsou hlavním konceptem recenzované knihy, která se soustředí na roli osobní oběti. Tu doplňují sociální vztahy lásky a péče, kult předků a požadavek synovské oddanosti. Ve vietnamských rodinách jsou tato pravidla pevná a projevují se v jazykových prostředcích komunikace (např. matka-dítě), které autorka lingvisticky analyzuje a dokládá fotografiemi komunikačních situací. Recenze poukazuje na alternativní výklady a kulturní specifika živých tradic magického myšlení a polygamie.
\end{abstract}

\section{Keywords}

Contemporary Vietnam; Postwar development; Family relations; Social imperatives; Anthropology.

\section{Úvod}

Cílem této glosy je přiblížení pozoruhodné knihy, která letos vyšla v nakladatelství University of California Press pod titulem Silence and Sacrifice. Family Stories of Care and the Limits of Love in Vietnam. Autorkou je antropoložka Merav Shohet, která se i díky terénnímu výzkumu zaměřila na podmínky a změny v rodinných vztazích v soudobém Vietnamu. Pro českého čtenáře je kniha zvlášt' cenná. Umožňuje nahlédnout do interního prostředí vietnamských rodin, tedy do světa, který obvykle není lidem ze západu dostupný ani u Vietnamců v ČR. Přitom jsou dobré důvody předpokládat, že ani česká společnost nedokáže vhodně chápat původní vietnamská východiska. I český etnolog Stanislav Brouček [1], který věnuje výzkumu Vietnamců celou aktivní kariéru, poukazuje na zásadní odstup, který si Vietnamci i vůči němu uchovávají. Války 20. století daly Vietnamu do vínku nesmazatelný otisk, který se projevuje na všech úrovních. A kniha od Shohet je jedna z mála, která si všímá toho, jak se války promítají až do vztahů v rodinách.

\section{Dopady historie a tradic na sociální vztahy}

Autorka začala s výzkumem ve své dizertaci roku 2010 a ve Vietnamu byla díky několika grantům asi rok a půl $\mathrm{v}$ terénu. To samo by jí $\mathrm{k}$ vhledu nestačilo. Dveře do vietnamských rodin jí otevíralo nadcházející manželství s etnickým Vietnamcem, a to, že se zaměřila na rodiny s prŕibuznými v USA. To však hrálo roli pouze vstupního kontaktu. Přes studium v USA se autorka soustředila na syrové sociální podmínky rodin, které neutekly do zahraničí, ale zůstaly ve Vietnamu. Odtud i poněkud zneklidňující název celé knihy, která je však pro poznání reálií velmi př́nosná. 
I když je téma osobní oběti (hy sinh) citlivé, výzkum Shohet umožnilo její vietnamské manželství a otevřenost spřátelených rodin. Díky nim se mohla věnovat hlavnímu tématu, a to projevům lásky a péče (tìhn cảm) na pozadí negativních impaktů války. Zde se Shohet odkazuje už na vynikající studii Kwona zaměřenou na rituální oběti duším těch, kteří padli ve válce [2].

Přes místy emočně bolestivé téma se etnograficky pojatá kniha př́ijemně čte, protože je psána z pohledu účastníka pozorování. Autorčinou hlavní výzkumnou otázkou je: jak násilné rozdělení rodin a složité sociální podmínky ovlivňují rodinné vazby. Autorka sledovala několik hlavních postav a zaměřuje se na to, jak prožité utrpení nadále ovlivňuje jejich životy.

První část knihy se třemi kapitolami nazvaná "Sustaining National and Family Sacrifice," zkoumá pojetí obětování, asymetrické vztahové reciprocity v projevech lásky a péče (tình cảm).

Hlavním podkladem první kapitoly je př́iběh Tana, nacionálně orientovaného válečného zajatce, který byl nasazen v bojích. Na jeho př́ikladu je vidět, že tichost sebeobětování a lásky je naplněna bolestí, která je osobní a nachází transcendenci teprve v patriotismu. Autorka se snaží ukázat, jak se potichu prožívané utrpení po čase stává vnitřně přijatou obětí, která se propojuje $\mathrm{s}$ láskou a péčí o druhé. Tan byl původně okolnostmi donucen sloužit ve francouzské armádě a až později přešel na stranu revoluce, kdy přitom zažil těžké mučení a byl i vězněn. Následně pracoval na Ho Či Minově stezce a za druhé (vietnamské/americké) války sloužil opět u vojska, kdy popisoval velmi složité potravinové podmínky. Ve vzpomínkách přitom nejmenoval žádné politické představitele s výjimkou „strýčka Hô“, tj. Ho Či Mina. Autorka přiznává, že jí jeho patriotický narativ bez dalších postav zklamal, protože silně připomínal pouhé stranické poučky a fráze. Sama však následně přiznala, že dobové historické knihy vychází jen z takových záznamů a zvlášt' ve Vietnamu vytváří specifický žánr komunistickou stranou (nebo obecně aktuální elitou) stvrzených oficiálních historických výkladů lý lịch [3, s. 52, 57]. Autorka cituje jedno z takových kolektivní vyjádření a heslo "není nic cennějšího než nezávislost a svoboda", které se pro Tana stalo živou realitou. Toto vodítko mu dříve ve válce umožňovala přežívat a pokračovat $\mathrm{v}$ dalším životě.

Je třeba přiznat, že některé $\mathrm{z}$ autorčiných komentár̆ù často nejsou kompatibilní $\mathrm{s}$ vietnamskými oficiálními výklady (kde by autorka narazila) a už od začátku je třeba s nimi pracovat tak, že jsou nevietnamskou reflexí vlivů z minulosti, které dále formují aktivní pamět' a oficiální porozumění minulosti.

Druhá kapitola prripojuje kontext kultu předků ve vztahu k morální subjektivitě. Oběti, které přinesli předkové, se rituálně aktualizují v paměti živých potomků, kteří musejí demonstrovat synovskou oddanost a úctu (hiếu). Shohet se přitom zaměřuje na to, jak se chápání oběti projevuje v praktických hierarchických vztazích. Vysvětlení jí poskytli informanti. Shohet zdůrazňuje, že zejména ve společnosti, která privilegizuje muže, lze jako obět' chápat většinu aspektů osobního života žen. Praktické př́klady komunikace a užitých jazykových prostředků vyžadujících respekt Shohet popisuje v konkrétních situacích, které dokládá fotografiemi konkrétní komunikace matky a dítěte [3, s. 88-92], kde je zdůrazněna imperativita jazykových prostředků užitých matkou a tradiční neosobnost vyjádření dítěte. Asijské jazyky se v tomto tradičním kontextu vyhýbají osobnímu zájmenu ve vyjádření (tedy ich-formě) a toto jazykové hledisko migranti zažívají více až v zahraničí.

Třetí kapitola se věnuje nerovnosti mezi pohlavími $\mathrm{v}$ kontextu sociální zkušenosti s “oficiálním státním patriotismem, očekáváním vázaným na podmínky pracoviště, mezigeneračních aspirací, a manželské touhy." Shohet tyto situace ukazuje na příkladu mladé ženy, která se po sjednocení země mohla řadit $\mathrm{k}$ zástupcům střední třídy, ale současně 
pečovala o svou babičku, čímž byla omezena na osobním životě. V takovém prípadě se částečná útěcha ve Vietnamu i dnes hledává u předpovídačů budoucnosti. Ve vietnamské společnosti se tradičně věřilo $\mathrm{v}$ numerologii a relativně krátký vliv soudobého komunismu (navíc ve vietnamské pragmatické formě) to nemohl změnit. Nelze proto př́liš přijmout ironii, se kterou Shohet popisuje rituály hledání lásky přes vykladačky karet $s$ dovětkem, že tyto socialismem odsuzované feudální aktivity se nyní volně tolerují [3, s. 106]. V tradiční kultuře tyto zvyky nebyly zpochybněny. Naopak složité podmínky života v současném Vietnamu je udržují jako velmi živou tradici. Podobně zbytečný odstup Shohet ukazuje, když popisuje hrdinku jednoho příběhu, která se stala milenkou ženatého muže a začala žít v milostném trojúhelníku př́mo v domě svého lépe postaveného milence, protože udržovala velmi dobré vztahy $\mathrm{s}$ jeho matkou. Shohet situaci a pocity dané ženy vnímá optikou svého antropologického přistupu jako obět'. Vztah však může mít i úplně jiné vysvětlení tradiční polygamie, která z vietnamské společnosti také nikdy zcela nevymizela.

Druhá část má název "Care Narratives and the Limits of Love" a její dvě kapitoly dále ukazují, jak se rodinné konflikty tlumí přes sociální imperativy. Jednotlivci to prritom řeší různými individuálními cestami. Autorka se v této části zaměřuje na jazykové prostředky a doklady z každodenních interakcí, aby ukázala, jak jsou protiklady bolesti života a požadavku lásky a péče zahrnuty do kulturní sféry a jak ambivalentně je jednotlivé postavy prožívají v dynamice prŕibuzenských a sousedských vztahů. Autorka si všímá toho, jak se osobní obět' a tình cảm projevují v životě členů rodiny např́klad v kritickém období těžké nemoci starší ženy, které se rychle horší zdravotní stav. Shohet opět uvádí jazykové prostředky a komunikační situace dokládá fotografiemi. Je třeba přiznat, že bez jejího upozornění by řada norem zůstala nepovšimnuta.

Následující kapitola diskutuje morální integritu, obět' a lásku v pragmatickém kontextu ženských emocí a tužeb. Přitom na mnoha místech knihy je hlavní termín tình cảm kontextuálně vysvětlen jiným způsobem, který poukazuje na složitější sít' významů. Na jiných místech je termín vyložen jako "affection rooted in mutual understanding and support" nebo jako "material provisioning motivated by love and care" [3, s. 177, 194]. Kapitola zdůrazňuje morální a jiné těžkosti a ukazuje, jak složité může být pečovat o př́buzné za podmínek obvyklé sociální kontroly. Autorka shromáždila př́klady čtyř žen v morálně ambivalentních situacích. Z nich nejkřiklavější je prrípad ovdovělé matky, která se věnuje prostituci, aby tak finančně podpořila syna na studiích, a také když je později ve vězení. Nakonec o syna pečuje i poté, co se nakazí nemocí AIDS, aby pak jako poslední akt lásky uspořádala rituálně správný pohřeb, aby synovi a jeho duši zajistila snazší přechod na druhou stranu [3, s. 182].

Poslední část knihy nadepsanou jako "Mourning in Silent Sacrifice", autorka využívá ke zdůraznění toho, jak se projevují jinak přímo nevyjádřené formy oběti, které jsou od členů rodiny a prátel očekávány jako demonstrativní akt péče, projevu respektu, a vzdání se sebe sama vůči blízkým př́ibuzným, kteří se někdy nebo i často chovají nevhodně. Autorka se tím snaží ukázat, jak se materializují príbuzenské vztahy a sjednocuje rozsáhlá rodina, kde truchlení vnímá jako klíč chápání morálního života.

\section{Závěr}

Kniha je sice trochu nadmíru zahleděna do morálních kontextů, které praktický život mnohdy ignoruje, ale je třeba přiznat, že právě na těchto imperativech staví pravidla konfuciánské morálky. V každém př́padě kniha patří $\mathrm{k}$ dílům základního výzkumu v kulturní antropologii a měla by být povinnou četbou všech akademiků, kteří se zajímají o Vietnam. Primárně je tato kniha určena právě čtenářské obci v zahraničí, tj. mimo Vietnam. 
Je velmi paradoxní, že zvláště mezi etnickými Vietnamci narozenými ve Vietnamu a lidmi v zahraničí přetrvává přes dílčí prátelství jakási propast, kterou nelze snadno překonat, a kterou může jen opatrně překlenovat řetězec interkulturních pracovníků z obou etnik. Přesto však i zde probíhají koncové komunikace odděleně, takže mezikulturní soužití má zjevné limity.

Autor této glosy byl při četných cestách po Asii i během pobytů ve Vietnamu opakovaně svědkem rodinného mezigeneračního násilí a nepředstíraného pláče při ranních obětech předkům. Přesto nebo právě proto jsou láska a oddanost popisované v knize a předepisované ve vietnamské kultuřre spíše bezbřehým citem. Možná by proto přes všechnu hořkost a jinde v literatuře definované „násilí každodenního života“ [4, s. 17] šlo dát knize o něco vřelejší podtitul: Family Stories of Care and Love in Vietnam. S odkazem na tuto modifikaci knihu vřele doporučuji jako důležitou četbu pro historiky, antropology a všechny, kdo se zajímají o Vietnam či východní Asii.

\section{Literatura}

[1] BROUČEK, Stanislav: The Visible and Invisible Vietnamese in the Czech Republic. The Problems of Adaptation of the Modern-Day Ethnic Group in the Local Environment of the Czech Majority. Institute of Ethnology, CAS, Prague, 2016.

[2] KWON, Heonik: Ghosts of War in Vietnam. Cambridge University Press, Cambridge New York, 2008.

[3] SHOHET, Merav: Silence and Sacrifice. Family Stories of Care and the Limits of Love in Vietnam. University of California Press, Oakland, 2021. ISBN 9780520379381.

[4] ELIAS, Juanita; RETHEL, Lena (eds.): The Everyday Political Economy of Southeast Asia. Cambridge University Press, Cambridge, 2016. Online ISBN 9781316402092. DOI: $\underline{10.1017 / C B O 9781316402092}$

Mgr. Michal Schwarz, Ph.D. 


\section{ANTHROPOLOGY OF SOCIAL RELATIONS IN CONTEMPORARY VIETNAM}

This review article presents a publication on ethnographic, linguistic, and social relations in the families that remained in Vietnam after the wars. Some family members still face post-war pressures and war trauma. Others face the social imperatives of caring for their elderly or sick relatives. Limitations in personal life are the main concept of the book reviewed which focuses on the role of the personal sacrifice. This is complemented by the social relations of love and care, the cult of ancestors and the demand for filial devotion. In Vietnamese families, these rules are fixed and are reflected in the linguistic means of communication (e.g., mother-child), which the author analyses from the linguistic point of view and documents it with the use of photographs of communication situations. The review points to alternative interpretations and cultural specifics of living traditions of magical thinking and polygamy.

\section{DIE ANTHROPOLOGIE DER SOZIALEN BEZIEHUNGEN IM HEUTIGEN VIETNAM}

Dieser Rezensionsartikel hat das Ziel, eine Publikation über die ethnografischen, linguistischen und sozialen Beziehungen in den Familien näherzubringen, welche nach den Kriegen in Vietnam geblieben sind. Einige Familienmitglieder sind noch immer einem Nachkriegsdruck ausgesetzt und haben mit Kriegstraumata zu kämpfen. Andere haben es mit den sozialen Imperativen der Fürsorge um die Alten oder kranke Verwandte zu tun. Einschränkungen im persönlichen Leben bilden das Hauptkonzept des rezensierten Buches, welches sich auf die Rolle des persönlichen Opfers konzentriert. Diese wird ergänzt durch die sozialen Beziehungen der Liebe und Fürsorge und den Ahnenkult sowie durch die Anforderung der Sohnesergebenheit. In den vietnamesischen Familien sind die Regeln fest und finden Ausdruck in den sprachlichen Kommunikationsmitteln (z. B. Mutter - Kind), welche die Autorin linguistisch analysiert und mit Fotografien der Kommunikationssituationen belegt. Die Rezension weist auf alternative Deutungen und kulturelle Spezifika der lebendigen Traditionen des magischen Denkens und der Polygamie hin.

\section{ANTROPOLOGIA STOSUNKÓW SPOŁECZNYCH WE WSPÓŁCZESNYM WIETNAMIE}

W artykule recenzyjnym przybliżono publikację poświęconą stosunkom etnograficznym, lingwistycznym i społecznym $\mathrm{w}$ rodzinach, które po wojnach pozostały w Wietnamie. Niektórzy członkowie rodzin wciąż borykają się z powojennymi presjami i wojenną traumą. Inni mierzą się ze społecznym imperatywem troski o starych lub chorych krewnych. Podstawową koncepcją recenzowanej książki, która skupia się na roli osobistej ofiary, są ograniczenia w życiu osobistym. Rolę też uzupełniają stosunki społeczne dotyczące miłości i troski, kult przodków i wymóg synowskiego oddania. W wietnamskich rodzinach zasady te są mocno zakorzenione i przejawiają się w językowych środkach komunikacji (np. matka dziecko), które autorka analizuje pod względem lingwistycznym, uzupełniając zdjęciami sytuacji komunikacyjnych. Recenzja wskazuje na alternatywne interpretacje i specyfiki kulturowe żywej tradycji myślenia magicznego i poligamii. 